\title{
Anmeldelse: \\ EU til Nordpolen!
}

Af Martin Breum

Den arktiske region - inklusive

Grønland - udgør en stadig mere omskiftelig og uoverskuelig faktor i det geopolitiske. Olie, gas, strategiske mineraler, sikkerhedspolitik, klimaforandringer, kinesere, territoriale stridigheder - Arktis har alt, hvad storpolitiske dønninger skabes af. $\mathrm{Og}$ er det så lykkedes EU at indtage en passende rolle i denne dynamik?

Andreas Raspotnik: The European Union and the Geopolitics of the Arctic. Edward Elgar Publishing, 2018, 231 s.

Den fremadstormende unge Arktis-forsker Andreas Raspotnik fra Fridtjof Nansen-instituttet i Oslo har med krum hals kastet sig ud i besvarelsen af ovenstående alt andet end simple spørgsmål.

I the European Union and the Geopolitics of the Arctic redegør han på cirka 160 letlæste sider (plus gavmilde noter og litteraturhenvisninger) for, hvordan Arktis har fået en central rolle i EU's tænkning om unionens mest basale interesser:

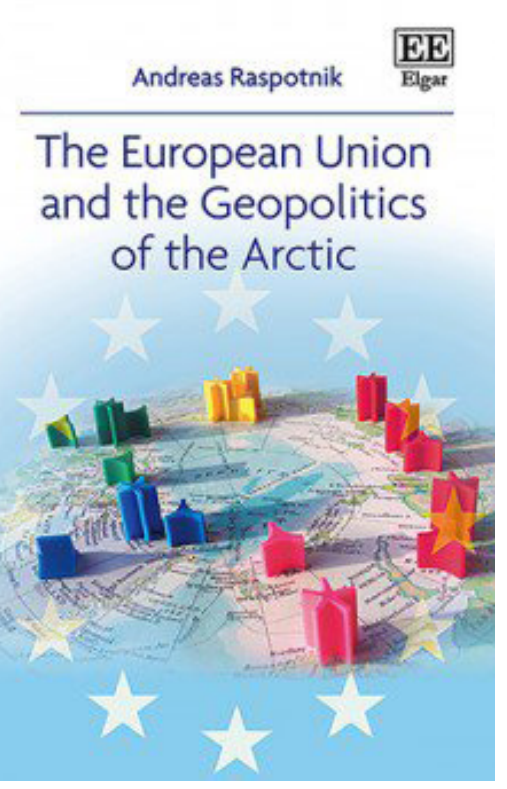

“Arktis opfattes som et naboområde præget af begyndende ustabilitet og usikkerhed - en uforudsigelighed, der kan forrykke EUropas stabilitet på en række måder. Desuden er effekterne af klimaforandringerne særlig stærke i Arktis, mens kilderne til disse forandringerne primært er eksterne.

Martin Breum er journalist og en af Danmarks førende iagttagere af udviklingen i Arktis og af rigsfællesskabet. Han er forfatter til bøgerne 'Cold Rush', 'Når isen smelter' og 'Balladen om Grønland'. 
Konklusionen er, at EUropæisk handling anses for uafvendelig", skriver han.

EU har med andre ord skabt sin egen forståelse af udviklingen i Arktis; en forståelse, der nu gør det pinedød nødvendigt at handle.

Problemet er, at det på denne handlingens front går ganske trægt. EU er ikke altid lige velkommen i Arktis; først Canada og i dag Rusland har det svært med EU i Arktis, og der er langt fra enighed i EU-kredsen om, hvor vigtig Arktis er for EU.

\section{Tre centrale forhold}

Raspotnik kortlægger med forbilledlig stringens en stribe centrale forhold; jeg nævner blot tre:

For det første har EU længe spillet en vigtig, omend diffus rolle i Arktis: EU-landene Sverige og Finland består delvist af arktiske landområder, der følgelig reguleres af EU-lovgivning; kongeriget Danmark omfatter som bekendt bl.a. de arktiske nationer Færøerne og Grønland, og selvom både Færøerne og Grønland står uden for EU, er de begge påvirket af EU via Danmarks medlemskab og i kraft af en række internationale aftalekomplekser, hvor EU spiller en rolle, og som har betydning for Nordatlanten.

Grønland nyder som det eneste af EU's såkaldte Overseas Countries and Territories godt af en særlig plads i EU's budget, og det har længe haft vigtige, faste indtægter fra fiskeriaftaler og en særlig partneraftale med EU. Norge og Island er begge en del af EEA og dermed det indre marked; $\mathrm{EU}$ er en vigtig aftager af fisk, rejer, mineraler, gas m.v. fra denne europæiske del af Arktis og en central sponsor af arktisk forskning. EU's medvirken til regulering af fiskeriet, af shipping på verdenshavene og af olieog gasefterforskning har stor betydning i Arktis, og industriproduktion i EU-landene bidrager konstant til den luftforurening i Arktis, der accelererer klimaforandringerne.

For det andet betyder Arktis en hel del for EU: Mineraler fra Grønland uran, sjældne jordarter mv. - kan blive afgørende for europæisk industri; arktiske fisk og rejer udgør en væsentlig del af kosten i EU; gassen fra Norge og den arktiske del af Rusland bliver stadig mere afgørende for EU's energisikkerhed. EU-systemet mener selv, at selve EU's legitimitet vil være i fare, hvis ikke det lykkes at samles om en seriøs, fælles indsats, der begrænser de klimaskader i Arktis, EU-landenes industri, kulafbrænding mv. bidrager til.

For det tredje er EU's handlemuligheder begrænsede af en række forhold: For eksempel af EU-institutionernes ganske forskelligartede tilgang; særlig Europa-Parlamentet har gang på gang markeret sig med fremstormende miljøinitiativer og krav om særlige FN-baserede Arktis-traktater mv., som har været stærkt upopulære blandt de arktiske nationer. Krimkrisen og sanktionerne mod Rusland hjælper heller ikke. Trods snart ti års diplomatisk pres er det endnu ikke lykkedes EU at blive fast observatør ved Arktisk Råd. Rusland blokerer fortsat - selvom Kina, Japan, Sydkorea og flere andre i mellemtiden har fået tildelt denne eftertragtede status. 


\section{Drømmen der brast}

Som Raspotnik skriver, formulerede Europa-Kommissionen i 2008 - ansporet af udsigten til store mængder arktisk olie og gas - en klar vision for EU's arktiske engagement. Et struktureret og velkoordineret EU-engagement i Arktis ville føre til nye samarbejder med de arktiske stater, som ville bidrage til øget regional stabilitet og til den rette balance mellem miljøbeskyttelse og bæredygtig udnyttelse af de arktiske ressourcer. En klassisk, attraktiv skrivebordsvision.

I dag ligger denne vision om ikke i ruiner, så i hvert fald alvorlig stækket. Den er afløst af en mere afdæmpet tilgang, men til gengæld også ifølge Raspotnik af en form for afklaring. EU's arktiske engagement dirigeres nu i stadig højere grad mod den arktiske forskning. Som Kina og andre med $ø$ nske om stærkere fodfæste i Arktis pumper EU-systemet stadig mere imponerende summer i forskningsaktiviteter i Arktis, forskningsinfrastruktur, ny teknologi, projektbevillinger osv.

De samlede investeringer ligger i dag i omegnen af 200 mio.euro, sådan at EU nu hører til de helt centrale finansielle kilder til den arktiske forskning. På et tidspunkt var det lige frem på tale at bygge en fælleseuropæisk isbryder til forskningen, men det blev dog for dyrt - og det er, som Raspotnik gør dejligt klart, for så vidt symptomatisk for hele engagementet. EU vil vældig gerne være en central aktør i Arktis, men Arktis ligger stadig meget langt fra Bruxelles.

000 